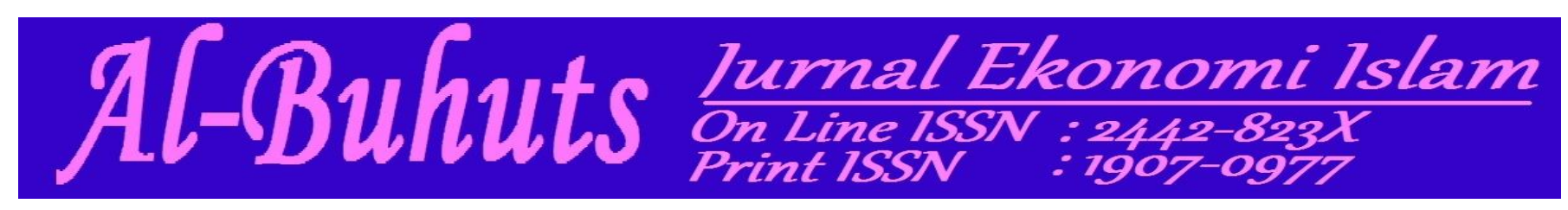

Volume. 13, Nomor 2, Desember 2017

\title{
Analisis Pengaruh Bauran Pemasaran Terhadap Keputusan Mahasiswa Memilih Kuliah di IAIN Parepare
}

\author{
Suherman \\ IAIN Parepare \\ idhasuher@gmail.com
}

\begin{abstract}
ABSTRAK
Peneltian ini dilakukan dengan tujuan untuk : (1) Menguji dan menganalisis pengaruh bauran pemasaran $7 \mathrm{P}$ yang meliputi product $(X 1)$, price $(X 2)$, place $(X 3)$, promotion (X4), people (X5), process (X6), dan physical evidence (X7) terhadap keputusan mahasiswa memilih kuliah di IAIN Parepare; (2) Menguji dan menganalisis variabel mana yang paling berpengaruh terhadap keputusan mahasiswa memilih kuliah di IAIN Parepare. Penelitian ini menggunakan data primer melalui survey sebanyak 100 orang sebagai sampel dari seluruh mahasiswa semester tiga IAIN Parepare pada tahun pelajaran 20172018. Survey dilakukan dari bulan Agustus s.d. September 2018. Data dianalisis melalui analisis regresi linier berganda dengan penggunakan program SPSS 21 Windows. Hasil penelitian ini menunjukkan bahwa; (1) Product berpengaruh postif dan signifikan terhadap keputusan Mahasiswa memilih kuliah di IAIN Parepare; (2) price berpengaruh negatif atau tidak berpengaruh terhadap keputusan Mahasiswa memilih kuliah di IAIN Parepare; (3) place berpengaruh postif dan signifikan terhadap keputusan Mahasiswa memilih kuliah di IAIN Parepare; (4) promotion berpengaruh postif dan signifikan terhadap keputusan Mahasiswa memilih kuliah di IAIN Parepare; (5) people berpengaruh negatif atau tidak berpengaruh terhadap keputusan Mahasiswa memilih kuliah di IAIN Parepare; (6) process berpengaruh postif dan signifikan terhadap keputusan Mahasiswa memilih kuliah di IAIN Parepare; (7) physical evidence berpengaruh postif dan signifikan terhadap keputusan Mahasiswa memilih kuliah di IAIN Parepare; (8) Promotion merupakan variabel paling berpengaruh terhadap keputusan Mahasiswa memilih kuliah di IAIN Parepare.
\end{abstract}

Kata Kunci : price, place, promotion, people, process, physical evidence

\section{Pendahuluan}

Pasca reformasi 1998, perguruan tinggi di Indonesia mengalami peningkatan yang cukup signifikan. Keberadaan perguruan tinggi tidak lagi hanya ditemukan di kota-kota besar provinsi, tetapi juga telah menjangkau dan tersebar ke kota-kota kabupaten. Jumlah perguruan tinggi yang terdaftar sudah mencapai ribuan dan tersebar di seluruh Indonseia baik negeri mau pun swasta. Pada 2017, berdasarkan data Kementerian Riset Teknologi dan Perguruan Tinggi (Ristek Dikti), jumlah unit perguruan tinggi mencapai 4.504 unit, 
yang terdiri atas 3.136 unit perguruan tinggi swasta dan 122 unit perguruan tinggi negeri. Sisanya adalah perguruan tinggi agama dan perguruan tinggi di bawah kementerian atau lembaga negara dengan sistem kedinasan.

Sebuah perguruan tinggi akan diminati banyak mahasiswa (kuantitas) jika perguruan tinggi tersebut memiliki kualitas (mutu) yang baik, sebaliknya perguruan tinggi yang tidak berkualitas akan ditinggalkan oleh peminat (mahasiswa). Pada intinya, salah satu persaingan perguruan tinggi itu terletak pada komponen mahasiswa sebagai pangsa pasar (konsumen). Semakin banyak mahasiswa yang berminat pada sebuah perguruan tinggi, itu berarti perguruan tinggi tersebut memiliki keunggulan kompetitif.

Mahasiswa merupakan bagian terpenting dari sebuah perguruan tinggi. Banyaknya perguruan tinggi sebagai alternatif akan memberikan keleluasaan bagi seorang mahasiswa untuk memilih dan memilah dimana mereka melanjutkan pendidikannya. Ada banyak variabel yang akan mempengaruhi keputusan mereka dalam menentukan pilhannya. Mahasiswa merupakan variabel konsumen dari perguruan tinggi sebagai industri jasa. Perilaku mahasiswa akan terbaca dalam teori perilaku konsumen. Konsumen dalam melakukan pembelian akan dipengaruhi oleh faktor budaya, sosial, pribadi mau pun psikologis. Bahkan sebelum mengambil keputusan pembelian mereka akan melalui proses tahapan yang meliputi pengenalan kebutuhah, pencarian informasi, evaluasi alternatif, keputusan pembelian dan perilaku pasca pembelian (Kotler, 2000).

Dalam pendekatan bisnis, untuk memperoleh peluang dan merebut pasar (konsumen) diperlukan pendekatan pemasaran. Bauran pemasaran merupakan inti dari sistem pemasaran modern yang dapat diadopsi dan diterapkan di perguruan tinggi. Melalui strategi bauran pemasaran, pengembangan dan pengelolaan perguruan tinggi berorientasi pada kualitas pelayanan dan mutu pada semua aspek. Menurut Kismono (2001:308) bauran pemasaran adalah kombinasi dari variabel atau kegiatan yang merupakan inti dari pemasaran yang terdiri dari strategi produk (product), harga (price), promosi (promotion), dan distribusi (place). Radiosunu (1993) menyatakan bahwa melalui penerapan bauran pemasaran, sebuah perusahaan dapat mempengaruhi tanggapan dan keputusan konsumen karena dalam bauran pemasaran terdapat beberapa variabel penting, yaitu produk, harga, promosi, tempat, orang, proses dan pelayanan. Lapiyoadi (2006) juga menyebutkan bauran pemasaran yang meliputi produk, harga, promosi, tempat, orang, proses dan pelayanan akan menjadi pertimbangan konsumen dalam menetapkan keputusan pembeliannya. 
IAIN Parepare sebagai salah satu lembaga pendidikan yang eksis di daerah, tentunya memerlukan pendekatan strategi pemasaran. Mampukah IAIN Parepare meyakinkan dan memperoleh kepercayaan masyarakat. Karena pengembangan dan pembangunan perguruan tinggi sangat ditentukan seberapa banyak minat dan dukungan masyarakat terhadap perguruan tinggi tersebut.

\section{Tinjauan Pustaka}

\section{A. Teori Pemasaran Jasa}

Perkembangan pemasaran jasa disebabkan pertumbuhan industri jasa murni (pure service), seperti travel, kesehatan, jasa finansial, pendidikan dan komunikasi. Maka muncul berbagai usaha untuk mengidentifikasi perbedaan dan persamaan pada industri. Usaha untuk menerapkan teknik pemasaran pada sektor jasa telah membawah pembaruan penting dalam konsep pemasaran. Ketika Levit (1981) menuliskan artikel intangible yang melahirkan pertanyaan is marketing of services different from the marketing goods? jawabannya adalah: "the principles may be the same, but the translation into practice may be profoundly different".

Philip Kotler, ahli pemasaran mendefinisikan pemasaran dalam dua tinjauan, yaitu sosial dan manajerial. Dalam tinjauan sosial, Kotler menyatakan pemasaran adalah suatu proses sosial yang di dalamnya individu dan kelompok mendapatkan apa yang mereka butuhkan dan inginkan dengan menciptakan, menawarkan, dan secara bebas mempertukarkan produk yang bernilai dengan pihak lain. Sementara, dalam tinjauan manajerial pemasaran adalah seni menjual produk $(2002,9)$.

\section{B. Teori Bauran Pemasaran}

Dalam konsep pemasaran terdapat strategi pemasaran yang disebut bauran pemasaran atau marketing mix. Strategi bauran pemasaran memiliki peranan penting dalam mempengaruhi konsumen dalam mengambil keputusan terhadap pembelian atau penggunaan suatu produk atau jasa. Untuk memahami konsep dasar bauran pemasaran, maka dikemukakan pendapat beberapa ahli pemasaran sebagai berikut: 
1) Phillip Kotler \& Armstrong (1997) menyatakan bahwa bauran pemasaran merupakan kumpulan alat pemasaran taktis terkendali yang dipadukan sebuah perusahaan untuk menghasilkan respon dan ekspektasi pasar/konsumen.

2) Zeithaml dan Bitner yang dikutip Ratih Hurriyati $(2005,28)$ menjelaskan pengertian bauran pemasaran sebagai elemen-elemen organisasi perusahaan dalam melakukan komunikasi dengan konsumen dan akan dipakai untuk memuaskan konsumen.

3) Daryatno $(2011,20)$ menyebutkan bauran pemasaran jasa sebagai seperangkat alat pemasaran taktis yang dapat dikendalikan dan dipadukan oleh perusahaan untuk menghasilkan respon yang diinginkan dalam pasar sasaran.

4) Fandy Tjiptono $(2007,30)$ mendefinisikan bauran pemasaran sebagai seperangkat alat pemasaran yang digunakan perusahaan untuk terus menerus mencapai tujuan pemasarannya di pasar sasaran.

5) Buhari Alma (2017) mengatakan bauran pemasaran adalah strategi mencampur kegiatan-kegiatan marketing, agar dicari kombinasi maksimal sehingga mendatangkan hasil yang paling memuaskan.

Dari pengertian para ahli tersebut di atas dapat disimpulkan bahwa bauran pemasaran merupakan kumpulan beberapa variabel sumber daya suatu perusahaan yang digunakan untuk membangun dan menarik respon pasar/konsumen agar mereka membeli atau menggunakan produk barang atau jasa yang ditawarkan.

Lapiyoadi (2001) dalam bukunya yang berjudul Manajemen Pemasaran Jasa; Teori dan Praktik menjelaskan mengenai kumpulan variabel dari bauran pemasaran. Ada pun variabel bauran pemasaran tersebut, yaitu a) Product (produk); b) Price (harga); c) Promotion (promosi); d) Place (tempat); e) People (orang); f) Process (Proses) dan g) Physical evidence (sarana fisik).

Varibel-variabel bauran pemasaran tersebut lebih dikenal kenal dengan sebutan marketing mix $7 P$. Untuk memperoleh gambaran yang lebih detail dari variabel bauran pemasaran $7 \mathrm{P}$, maka diuraikan sebagai berikut :

\section{1) Product (produk)}

Produk merupakan hasil proses produksi dari pubrik atau perusahaan dalam bentuk jasa atau barang. Purnama (2001) menyatakan produk merupakan segala sesuatu yang dapat ditawarkan kesuatu pasar untuk memenuhi keinginan dan kebutuhan. Kotler (1993) menyatakan produk adalah segala sesuatu yang bisa ditawarkan kepada sebuah pasar agar 
diperhatikan, diminta, dipakai, atau dikonsumsi sehingga mungkin memuaskan keinginan atau kebutuhan.

Faktor yang perlu diperhatikan dalam permasalahan produk adalah konsumen tidak hanya membeli fisik dari produk itu saja tetapi membeli benafit dan value dari produk tersebut. Purnama (2001) menyatakan terdapat tujuh tingkat hirarki produk, yaitu : a) Keluarga kebutuhan (need family). b) Kelas produk (product class). c) Lini produk (product line). c) Jenis produk (product type), d) Merek (brand), e) Unit produk (item/stockkeeping unit/product variance).

2) Price (harga)

Stanton (1996) berpendapat bahwa harga adalah sejumlah uang dan atau sesuatu yang lain beserta faedahnya yang dibutuhkan untuk mendapatkan suatu produk dan jasa. Menurut Payne (2001) keputusan-keputusan penetapan harga sangat signifikan dalam menentukan nilai bagi pelanggan dan memainkan peran sangat penting dalam pembentukan citra bagi jasa tersebut. Purnama (2001) menyatakan suatu perusahaan harus menempatkan harga untuk pertama kalinya, yaitu ketika;

a. Perusahaan tersebut mengembangkan atau memperoleh suatu produk baru;

b. Perusahaan tersebut baru pertama kalinya memperkenalkan produk reguler ke saluran distribusi atau daerah baru;

c. Perusahaan akan mengikuti lelang atas suatu kontrak kerja baru;

Menurut Lupiyoadi (2001) keputusan penetapan harga juga sedemikian penting dalam menentukan seberapa jauh pelayanan layanan jasa dinilai oleh konsumen, dan juga dalam proses membangun citra. Kegiatan penetapan harga memainkan peran penting dalam proses bauran pemasaran karena penetapan harga terkait langsung nantinya dengan revenue yang diterima oleh perusahaan.

3) Place (tempat)

Phillip Kotler (1993) menyatakan saluran distrubusi terdiri seperangkat lembaga yang melakukan semua kegiatan atas fungsi yang digunakan untuk menyalurkan produk dan status kepemilikannya dari produksi ke konsumen. Masalah pemilihan saluran distribusi adalah suatu masalah yang sangat penting, sebab salah dalam pemilihan distribusi dapat memperlambat bahkan dapat menghentikan usaha penyaluran barang dan jasa dari produsen barang dan jasa ke konsumen. 
Menurut Kotler dan Keller (2007:128) saluran pemasaran melaksanakan sejumlah fungsi utama antara lain:

a. Mengumpulkan informasi mengenai calon pelanggan dan pelanggan sekarang, pesaing, dan pelaku serta kekuatan lainnya dalam lingkungan pemasaran tersebut.

b. Mengembangkan dan menyebarkan komunikasi persuasif untuk merangsang pembelian.

c. Mencapai kesepakatan mengenai harga dan ketentuan-ketentuan lain sehingga peralihan kepemilikan dapat terlaksana.

d. Melakukan pemesanan kepada produsen.

e. Memperoleh dana untuk membiayai persediaan pada tingkat yang berbeda dalam saluran pemasaran.

f. Menanggung risiko yang berhubungan dengan pelaksanaan fungsi saluran.

g. Mengatur kesinambungan penyimpanan dan perpindahan produk-produk fisik.

h. Mengatur pelunasan tagihan mereka kepada pembeli melalui bank dan lembaga keuangan lainnya.

i. Mengawasi peralihan kepemilikan aktual dari suatu organisasi atau orang kepada organisasi atau orang lainnya.

\section{4) Promotion (promosi)}

Stanton (1996) menyatakan bahwa pada dasarnya promosi adalah sesuatu kegiatan memberitahukan (information), membujuk (persuation), dan mempengaruhi (influentce). Sedangkan Winardi (1990) menyatakan promosi merupakan aktivitas-aktivitas sebuah perusahaan yang dirancang untuk memberikan informasi, membujuk atau mengingatkan pihak-pihak lain tentang perusahaan yang bersangkutan dan barang-barang serta jasa-jasa yang ditawarkan.

George dan Berry dalam payne (2001) mengidentifikasi enam pedoman untuk pemasaran jasa yang benar-benar dapat diterapkan untuk kebanyakan unsur bauran pemasaran promosi, yaitu;
a. Memberikan petunjuk berwujud
b. Membuat jasa dimengerti
c. Kesinambungan komunikasi
d. Menjanjikan apa yang mungkin diberikan
e. Mengkapitalisasi word of mouth 
f. Komunikasi langsung kepada konsumen

5) People (Orang)

Yazid (2001) mengatakan orang (people) adalah semua pelaku yang memaikan sebagian penyajian jasa dan karenanya mempengaruhi persepsi pembeli. Lupiyoadi (2001) menjelaskan 4 kriteria peranan atau pengaruh dari aspek orang (people) yang mempengaruhi konsumen, yaitu peran sebagai berikut;

a. Contractor, people di sini berinteraksi langsung dengan konsumen dalam frekuensi yang cukup sering dan sangat mempengaruhi keputusan konsumen untuk membeli.

b. Modifier, mereka tidak secara langsung mempengaruhi konsumen, tetapi cukup sering berhubungan dengan konsumen, misalnya resepsionis.

c. Influencer, mereka ini mempengaruhi konsumen dalam keputusan konsumen untuk membeli tetapi tidak secara langsung kontak dengan konsumen.

d. Isolated, people ini tidak secara langsung ikut dalam marketing mix dan juga tidak sering bertemu dengan konsumen. Misalnya karyawan bagian administrasi penjualan, SDM, dan data processing.

6) Process (Proses)

Lupiyoadi (2001) menyatakan bahwa proses merupakan gabungan semua aktivitas, umumnya terdiri dari prosedur, jadwal pekerjaan, aktivitas dan hal-hal rutin, dimana suatu jasa dihasilkan dan disampaikan kepada konsumen. Proses dapat dibedakan dalam 2 cara, yaitu;

a. Kompleksitas (Complexity), hal ini berhubungan dengan langkah dan tahap dalam proses. Kompleksitas mencerminkan sejumlah langkah yang terlibat dalam penyampaian jasa.

b. Fleksibilitas (Divergence), berhubungan dengan adanya perubahan dalam langkah atau tahap proses. Fleksibilitas mencerminkan rentang (naik turunnya level) eksekusi atau variabelitas langkah - langkah tersebut.

7) Physical Evidence (bukti fisik)

Menurut Zeithaml dan Bitner (1996), physical evidence (bukti fisik) adalah lingkungan tempat jasa disampaikan dan tempat penyedia jasa dengan konsumen berinteraksi berserta dengan semua komponen lainnya yang mendukung terwujudnya komunikasi jasa. 
Bagian dari bukti fisik termasuk seluruh aspek fasilitas fisik dari penyedia jasa yang terdiri dari atribut eksterior dan interior serta hal berwujud lainnya. Desain eksterior selalu dikaitkan dengan seni atau keindahan, dimana eksterior adalah cerminan awal dari pengunjung dalam beraktivitas. Sementara lingkungan interior merupakan penampilan dalam gedung-gedung perkantoran.

\section{Teori Keputusan Pembelian Konsumen}

Jual beli merupakan salah satu kegiatan yang tidak bisa terlepas dalam aktivitas kehidupan manusia. Sebelum melakukan pembelian, sesorang biasanya akan melakukan keputusan terlebih dahulu terhadap suatu produk. Keputusan pembelian konsumen merupakan tindakan konsumen untuk memilih dan membeli sebuah produk barang atau jasa yang tersedia.

Kotler (2002) yang mendefenisikan keputusan pembelian konsumen sebagai suatu tindakan dari konsumen untuk mau atau tidak membeli terhadap produk. Pengertian lain dikemukakan Schiffman and Kanuk $(2000,437)$ "the selection of an otion from two or alternative choice". Artinya, keputusan pembelian adalah suatu keputusan seseorang dimana dia memilih salah satu dari beberapa alternatif pilihan yang ada. Helga Drumond (2003, 68) yaitu mengidentifikasikan semua pilihan yang mungkin untuk memecahkan persoalan itu dan menilai pilihan-pilihan secara sistematis dan objektif serta sasarannya yang menentukan keuntungan serta kerugian masing-masing.

1. Faktor yang mempengaruhi keputusan konsumen

Menurut Engel (1994), ada 2 faktor yang mempengaruhi keputusan konsumen dalam pembelian yaitu;

a. Sikap atau pendirian orang lain. Tingkat kesukaan atau ketidaksukaan orang lain terhadap suatu produk barang atau jasa akan memberikan motivasi pembelian barang atau jasa.

b. Faktor situasi yang tidak bisa diantisipasi. Misalnya faktor pendapatan, harga, atau manfaat barang atau jasa yang diinginkan.

Sementara Phillip Kotler menyebut ada 4 faktor yang mempengaruhi pengambilan keputusan konsumen, yaitu 
a. Faktor budaya.

Budaya merupakan faktor penentu keinginan atau pun kebutuhan dan perilaku yang paling dasar. Sub budaya meliputi kebangsaan, agama, kelompok ras dan wilayah geografis. Kelas sosial merupakan pembagian strata sosial masyarakat yang bersifat homogen dan permanen, dimana mereka memiliki minat, nilai, corak, dan perilaku yang identik.

b. Faktor Sosial.

Hubungan dan status sosial seseorang juga berpengaruh terhadap keputusan pembelian terhadap sutau barang atau jasa. Faktor sosial itu dapat dibagi dalam 3 bagian, yaitu; kelompok acuan, keluarga, dan peran atau status sosial.

c. Faktor pribadi

Penggunaan atau pembelian terhadap suatu barang dan jasa sangat dipengruhi oleh karakter seorang individu. Karakteristik tersebut meliputi usia dan siklus hidup, pekerjaan, keadaan ekonomi, gaya hidup, serta kepribadian.

d. Faktor psikologis

Keputusan pembelian konsumen dipangaruhi oleh faktor psikologis yang meliputi; motivasi, persepsi, pembelajaran, keyakinan dan sikap.

\section{Proses Keputusan Pembelian}

Menurut Phillip Kotler, ada lima 5 tahap proses yang dilalui konsumen dalam memutuskan pembelian, yaitu;

a. Pengenalan kebutuhan

Pengenalan kebutuhan merupakan tahap pertama proses keputusan pembeli yaitu ketika konsumen mengenali adanya masalah atau kebutuhan.

b. Pencarian informasi

Pencarian informasi adalah tahap dari proses keputusan pembeli, yang merangsang konsumen untuk mencari informasi lebih banyak, konsumen mungkin hanya meningkatkan perhatian atau mungkin aktif mencari informasi. Seorang konsumen yang sudah tertarik mungkin akan mencari lebih banyak informasi tetapi mungkin juga tidak.

c. Evaluasi alternatif 
Evaluasi alternatif merupakan tahap dari proses keputusan pembelian, yaitu ketika konsumen menggunakan informasi untuk mengevaluasi merek alternatif dalam perangkat pilihan.

d. Keputusan pembelian

Keputusan pembelian merupakan tahap dari proses pengambilan keputusan pembelian yaitu, ketika konsumen benar-benar membeli.

e. Tingkah laku pasca pembelian

Tingkah laku pasca pembelian merupakan tahap proses keputusan pembelian yaitu ketika konsumen mengambil tindakan lebih lanjut setelah membeli berdasarkan pada rasa puas atau tidak puas.

\section{Metode Penelitian}

\section{A. Pendekatan Penelitian}

Penelitian ini menggunakan metodologi peneltian kuantitatif dengan jenis penelitian expost facto. Penelitian expost facto lebih dikenal dengan sebutan penelitian kausal komparatif yang bertujuan untuk menguji dua variabel atau lebih memiliki pengaruh atau tidak, seberapa besar pengaruhnya, dan serta bagaimana arah dari pengaruh tersebut.

B. Metode pengumpulan data.

1) Kuesioner, yaitu daftar pernyataan secara tertulis yang diberikan kepada responden untuk memperoleh informasi atau data yang dibutuhkan dalam penelitian

2) Teknik dokumenter. Teknik atau proses untuk memperoleh data dengan jalan mengumpulkan, mencatat data-data yang dipublikasikan oleh lembaga atau instansi terkait

3) Teknik pustaka merupakan penelitian dengan mempelajari literatur di perpustakaan yang berhubungan dengan permasalahan dan digunakan untuk mencari landasan teori sebagai acuan dalam penelitian.

C. Metode Analisis Data

1) Uji Instrumen

a. Uji Validitas

Teknik pengujian yang digunakan adalah korelasi bivariate pearson (produk momen pearson). Uji validitas dilakukan dengan cara menghitung koefisien korelasi 
antara masing-masing pernyataan dengan jumlah skor total pernyataan. Jika $r$ hitung $\geq r$ tabel (uji 2 sisi dengan sig. 0,05) maka instrumen atau item-item pertanyaan berkorelasi signifikan terhadap skor total maka dinyatakan valid.

b. Uji Reliabilitas

Pengujian reliabilitas instrumen dengan menggunakan rumus Alpha Cronbach karena instrumen penelitian ini berbentuk angket dan skala bertingkat. Jika alpha $>0.90$ maka reliabilitas sempurna. Jika alpha 0.70-0.90 maka reliabilitas tinggi. Jika alpha 0.50-0.70 maka reliabilitasnya moderat. Jika alpha $<0.50$ maka reliabilitasnya rendah. Jika alpha rendah kemungkinan satu atau beberapa item tidak reliabel.

c. Uji asumsi klasik

Uji asumsi klasik merupakan persyaratan statistik analisis regresi liner berganda. Pengujian ini perlu dilakukan untuk mengetahui apakah hasil estimasi regresi yang dilakukan benar-benar bebas dari adanya gejala heteroskedastisitas, gejala multikolinieritas, atau gejala autokorelasi. Jika terdapat heteroskedastisitas, maka varian tidak konstan sehingga dapat menyebabkan bias standar error. Jika terdapat multikolinieritas, maka akan sulit untuk mengisolasi pengaruh-pengaruh individu dari variabel sehingga signifikasi koefesien regresi yang menjadi rendah. Sementara autokorelasi mengakibatkan penafsir masih bias dan tidak efisien (Sudrajat, 1998).

2). Analisis regresi

a. Analisis regresi linier berganda

Untuk menjawab kebenaran hipotesa dalam penelitian ini, maka peneliti menggunakan analisis regresi. Bentuk persamaan Regresi Linier Berganda sebagai berikut;

$$
Y=a+\beta_{1} X_{1}+\beta_{2} X_{2}+\beta_{3} X_{3}+\beta_{4} X_{4}+\beta_{5} X_{5}+\beta_{6} X_{6}+\beta_{7} X_{7}+e
$$

\section{Keterangan :}

$\mathrm{Y} \quad=$ Keputusan Mahasiswa

a $\quad=$ Kostanta

$\mathrm{e}=$ Standar Error (tingkat kesalahan)

$\mathrm{X}_{1}=$ Product $\quad \beta_{1}=$ Koefisien varibael $\mathrm{X}_{1}$

$\mathrm{X}_{2}=$ Price $\quad \beta_{2}=$ Koefisien varibael $\mathrm{X}_{2}$

$X_{3}=$ Promotion $\quad \beta_{3}=$ Koefisien varibael $X_{3}$

$\mathrm{X}_{4}=$ Place $\quad \beta_{4}=$ Koefisien varibael $\mathrm{X}_{4}$ 
$\mathrm{X}_{5}=$ People $\quad \beta_{5}=$ Koefisien varibael $\mathrm{X}_{5}$

$\mathrm{X}_{6}=$ Process $\quad \beta_{6}=$ Koefisien varibael $\mathrm{X}_{6}$

$\mathrm{X}_{7=}$ Physical evidence $\beta_{7}=$ Koefisien varibael $\mathrm{X}_{7}$

c. Uji signifikansi simultan (Uji F)

Untuk menguji signifikansi faktor-faktor bauran pemasaran secara bersama-sama terhadap keputusan mahasiswa memilih kuliah di IAIN Parepare, digunakan uji signifiknasi simultan/Uji Statistik F. Pada uji F ini, dengan tingkat kepercayaan 95\% atau ó $=0,05 \%$ dan perhitungan hasil nilai signifikan $\mathrm{F}$ lebih kecil dari alfa $=0,05 \%$ maka $\mathrm{H}_{0}$ ditolak dan $\mathrm{H}_{1}$ terima. Hal ini berarti variabel independennya secara bersama-sama berpengaruh secara signifikan terhadap variabel dependennya. Sebaliknya, jika perhitungan hasil nilai signifikan $\mathrm{F}$ lebih besar dari $\alpha=0,05 \%$ maka $\mathrm{H}_{0}$ diterima dan $\mathrm{H}_{1}$ ditolak. Hal ini berarti variabel-variabel independennya secara bersama-sama tidak berpengaruh secara signifikan terhadap variabel dependennya.

d. Uji signifikansi parsial (Uji T)

Uji T bertujuan untuk mengetahui seberapa besar pengaruh variabel indeenden secara individual dalam menerangkan variabel dependen dengan menguji koefisien regresi secara individual. Nilai $\mathrm{F}$ tabel akan dibandingkan dengan nilai $\mathrm{T}$ hitung. Jika nilai $\mathrm{T}$ hitung < dari $\mathrm{T}$ tabel, maka $\mathrm{H}_{0}$ akan ditolak. Hal itu berarti bahwa variabel independen berpengaruh terhadap variabel dependen. Sebaliknya, jika nilai $\mathrm{T}$ hitung $>$ dari $\mathrm{T}$ tabel, maka $\mathrm{H}_{0}$ akan diterima. Hal itu berarti bahwa variabel independen tidak berpengaruh terhadap variabel dependen.

\section{B. Pembahasan}

\section{Pengaruh product terhadap keputusan mahasiswa memilih kuliah di IAIN Parepare}

Menurut Fansy Tjiptono, pengertian product adalah segala sesuatu yang dapat ditawarkan produsen untuk diperhatikan, diminta, dicari, dibeli, digunakan, serta dikonsumsi pasar sebagai upaya pemenuhan kebutuhan dan keinginan pasar yang berkaitan. Hal itu berarti, product merupakan elemen penting bagi produsen sebagai penyedia dan konsumen sebagai suatu kebutuhan.

Hasil penelitian ini menunjukkan bahwa variabel product berpengaruh secara positif dan signifikan terhadap keputusan mahasiswa memilih kuliah di IAIN Parepare. Hal tersebut mengindikasikan bahwa indikator-indikator product berhubungan secara linier dengan 
keputusan mahasiswa. Jika variabel product tersedia, baik secara kualitatif atau pun kuantitatif maka akan berkontribusi terhadap keputusan mahasiswa dalam memilih kuliah di IAIN Parepare.

Ada pun indikator-indikator dari product dapat dijelaskan sebagai berikut :

a. Kualitas/mutu pendidikan menjadi bagian penting dari perguruan tinggi, jika kualitas/mutu pendidikan baik maka berdampak positif terhadap peningkatan jumlah mahasiswa pada sebuah perguruan tinggi. Sebaliknya, kualitas/mutu rendah atau buruk maka akan berdampak terhadap kurangnya minat mahasiswa memilih kuliah di perguruan tinggi tersebut. Dalam konteks pendidikan banyak pendapat tentang mutu. Namun demikian, kajian tentang mutu dalam pendidikan dapat ditinjau dari aspek input, proses, output dan dampak serta manfaat. Dari aspek ini, IAIN Parepare telah menunjukkan diri sebagai salah satu perguruaan tinggi yang cukup diunggulkan, khususnya di wilayah Ajatappareng dan sekitarnya.

b. Prospek lulusannya dalam memperoleh pekerjaan dan karir. Prospek lulusan dalam memperoleh pekerjaan dan karir menjadi bagian yang cukup berpengaruh bagi mahasiswa memilih kuliah pada sebuah perguruan tinggi. Dalam konteks ini, alumni IAIN Parepare telah terserap diberbagai pekerjaan, baik swasta mau pun negeri dan tersebar dalam dan luar Sulawesi-Selatan, bahkan luar ke luar negeri.

c. Banyak jurusan atau program studi. Program studi merupakan product yang sangat penting bagi perguruan tinggi. Semakin banyak program studi yang ditawarkan, akan memberikan keleluasaan bagi para mahasiswa memilih program studi yang diinginkan. Dalam konteks ini, IAIN Parepare telah mengembangkan dan menawarkan berbagai program studi yang terdiri 10 program studi pada jurusan Tarbiyah dan Adab, 10 program studi pada jurusan Syariah dan Ekonomi Islam, 6 program studi pada jurusan Dakwah dan Komunikasi, dan 6 program studi pada program Pascasarjana.

d. Status akreditasi. Akreditasi merupakan penentuan standar mutu dan penilaian suatu lembaga pendidikan (pendidikan tinggi) oleh pihak di luar lembaga yang independen. Dalam konteks ini, status IAIN Parepare merupakan perguruan tinggi negeri di bawah naungan kementerian agama RI dan telah mengalami perubahan dari bentuk sekolah tinggi menjadi institut dengan status akreditasi A. 


\section{Pengaruh price terhadap keputusan mahasiswa memilih kuliah di IAIN Parepare.}

Menurut Henry Simamora, price adalah nilai uang yang ditentukan secara global yang harus dikeluarkan oleh seseorang untuk mendapatkan suatu produk atau pelayanan jasa yang diinginkan. Perguruan tinggi sebagai industri jasa, tentunya menempatkan price sebagai variabel penting dalam pendidikan. Hasil pengujian simultan parsial atau uji $\mathrm{T}$ menunjukkan bahwa variabel price berpengaruh secara negatif atau tidak berpengaruh terhadap keputusan mahasiswa kuliah di IAIN Parepare.

Hal ini mengindikasikan ada hubungan yang tidak linier antara variabel price dengan keputusan mahasiswa. Artinya, jika price pendidikan yang dikeluarkan mahasiswa meningkat, maka keputusan mahasiswa memilih kuliah pada perguruan tinggi tersebut akan menurun. Sebaliknya, jika price pendidikan rendah maka keputusan mahasiswa memilih kuliah di perguruan tinggi tersebut akan meningkat. Temuan ini relevan dengan hukum permintaan yang berbunyi "Hubungan antara barang yang diminta dengan harga barang tersebut dimana hubungan berbanding terbalik yaitu ketika harga meningkat atau naik maka jumlah barang yang diminta akan menurun dan sebaliknya apabila harga turun jumlah barang meningkat.”

Ada pun indikator-indikator dari price dapat dijelaskan sebagai berikut :

a. Penentuan price atau biaya pendidikan yang terdiri atas komponen biaya SPP, biaya PPL, biaya pendaftaran, dan biaya lain-lainnya didasarkan pada kemampuan ekonomi masyarakat yang menjadi pangsa pasarnya. Kemampuan ekonomi masyarakat yang ada disekitar IAIN Parepare berada pada tingkat ekonomi menengah ke bawah. Sehingga, komponen biaya yang akan dikeluarkan selama proses perkuliahan di IAIN Parepare relatif terjangkau karena sesuai dengan kemampuan masyarakat.

b. Sistem pembayaran segala biaya pendidikan di IAIN Parepare cukup mudah, karena dilakukan langsung bank yang telah bermitra, seperti BNI.

c. Program beasiswa. Jika melihat jumlah mahasiswa, ketersediaan kuota beasiswa masih sangat terbatas.

\section{Pengaruh place terhadap keputusan mahasiswa memilih kuliah di IAIN Parepare.}

Place dalam bauran pemasaran disebut dengan saluran distribusi, saluran dimana produk tersebut sampai kepada konsumen. Bagi perguruan tinggi, saluran distribusi yang digunakan disebut kampus yaitu tempat atau pusat pemberian layanan perkualihan mahasiswa. 
Hasil penelitian ini menunjukkan bahwa variabel place berpengaruh secara positif dan signifikan terhadap keputusan mahasiswa memilih kuliah di IAIN Parepare. Hal tersebut mengindikasikan bahwa indikator-indikator variabel place berhubungan secara linier dengan keputusan mahasiswa. Jika variabel place tersedia maka akan berkontribusi terhadap keputusan mahasiswa memilih kuliah di IAIN Parepare. Aksebilitas dan jarak tempuh ke kampus menjadi faktor penting dari sebuah perguruan tinggi.

Ada pun indikator-indikator dari promotion dapat dijelaskan sebagai berikut :

a. Dalam konteks IAIN Parepare, letak kampusnya cukup strategis karena berada di kota Parepare. Sebuah kota yang strategis karena terletak pada jalur jalan lintas antar kabupaten di bagian utara Sulawesi Selatan dengan infra struktur jalan yang cukup memadai. Parepare juga menjadi kota penghubung antar pulau karena memiliki pelabuhan laut. Keberadaan pelabuhan ini, akan memudahkan orang untuk datang atau berkunjung ke Parepare.

b. Posisi kampus yang terletak di jalan poros Parepare - Pinrang - Sulawesi Barat memberi ruang aksebilitas kampus yang mudah terjangkau. Jalan masuk ke dalam kampus cukup baik dengan pintu masuk dari tiga arah. Tata letak gedung pun dihubungkan dengan jalanan yang bermaterial aspal atau beton dan dapat dilalui oleh kendaraan motor ataupun mobil.

c. Jarak kampus dengan kampung asal, juga menjadi faktor yang dipertimbangkan para respoden. Rata-rata mahasiswa yang menjadi responden berasal dari kota Parepare dan sekitarnya, yang meliputi kabupaten Pinrang, Sidenreng Rappang, Barru, Enrekang, Soppeng, Wajo dan kabupaten di Sulawesi Selatan. Fakta ini menunjukkan bahwa peminat terbesar dari IAIN Parepare, berasal dari daerah terdekat dari kota Parepare.

\section{Pengaruh promotion terhadap keputusan mahasiswa memilih kuliah di IAIN} Parepare .

Menurut Tjiptono, promotion adalah bentuk komunikasi pemasaran yang berusaha menyebarkan informasi, mempengaruhi/ membujuk dan atau mengingatkan pasar sasaran atas perusahaan dan produknya agar bersedia menerima, membeli, dan loyal pada produk yang ditawarkan perusahaan yang bersangkutan. Dalam bisnis modern, promotion itu menjadi bagian penting bagi perusahaan untuk menginformasikan produk yang mereka tawarkan secara lengkap dan detail kepada konsumen. 
Hasil penelitian ini menunjukkan bahwa variabel promotion berpengaruh secara positif dan signifikan terhadap keputusan mahasiswa memilih kuliah di IAIN Parepare. Hal tersebut mengindikasikan bahwa indikator-indikator promotion berhubungan secara linier dengan keputusan mahasiswa. Jika variabel promotion dilakukan dengan baik dan terprogram maka akan berkontribusi terhadap keputusan mahasiswa dalam memilih suatu perguruan tinggi. Perguruan tinggi harus memilih strategi promotion yang tepat, agar dapat mempengaruhi keputusan konsumen memilih kuliah di perguruan tinggi tersebut.

Ada pun indikator-indikator dari promotion dapat dijelaskan sebagai berikut :

a. Dalam konteks ini, IAIN Parepare telah melakukan promotion secara baik dengan tiga indikator di atas. Indikator penggunaan media dalam promosi di IAIN Parepare cukup maksimal. Mereka menggunakan semua potensi media komunikasi, baik konvensional mau pun modern (digital). Penyebaran informasi digalakkan melalui radio, surat kabar, dan membuat pusat informasi melalui internet. Berbagai alat peraga pun dicetak, seperti spanduk, baliho, stiker, kalender, dan lain-lain tersebar diberbagai tempat dan posisi strategis lainnya.

b. Sosialisasi program atau kegiatan-kegiatan yang terkait dengan IAIN Parepare, baik kegiatan intrakorikuler maupun ekstrakorikuler. IAIN Parepare secara intensif mensosialisasikan setiap kegiatannya melalui pemberitaan media, seperti surat kabar, media online, media sosial, dan pusat informasi kampus berbasis internet.

c. IAIN Parepare dalam mempromosikan kampusnya adalah kunjungan langsung ke sekolahsekolah. Kegiatan ini menjadi program rutin tahunan dengan mendatangi sekolah lanjutan, yaitu SMA, SMK, madrasah, dan pesantren. Seluruh civitas kampus, yakni para pimpinan, dosen, pegawai dan mahasiswa dilibatkan dalam program sosialisasi.

\section{Pengaruh people terhadap keputusan mahasiswa memilih kuliah di IAIN Parepare.}

Menurut Zeithaml dan Biner, people atau "orang" adalah semua manusia yang berperan di bagian pengantar jasa dan mempengaruhi persepsi pembeli yaitu personil perusahaan, konsumen dan konsumen lainnya di lingkungan jasa. Bagi perguruan tinggi, elemen people terdiri atas tenaga pendidik yang disebut dosen, dan tenaga kependidikan yang disebut pegawai. Hasil penelitian ini menunjukkan bahwa variabel people berpengaruh secara negatif atau tidak berpengaruh terhadap keputusan mahasiswa kuliah di IAIN Parepare. Hal ini mengindikasikan ada hubungan yang tidak linier antara variabel people dengan 
keputusan mahasiswa. Artinya, indikator-indikator dari variabel people tidak berkontribusi terhadap keputusan mahasiswa memilih kuliah di IAIN Parepare.

Adanya pengaruh yang tidak signifikan dari variabel people terhadap keputusan mahasiswa memilih kuliah di IAIN Parepare, dipengaruhi oleh peran dari indikator yang membentuknya. Indikator-indikator tersebut, yaitu;

a. Latar belakang pendidikan para dosen. Pada dasarnya, tenaga pendidik yang bekerja sebagai dosen telah memenuhi kualifikasi pendidikan, baik lulusan strata dua (S2) mau pun lulusan doktor (S3). Hanya saja, status kepegawaian mereka tidak semua dosen tetap (dosen negeri) karena sebagiannya dosen luar biasa yang tidak terikat secara formal. Dari sisi usia, rata-rata dosen yang mengajar masih muda (yunior) dan bahkan pengalaman pertama mengajarnya baru diperoleh di IAIN Parepare. Pada umumnya, mahasiswa lebih banyak mengharap diajar oleh dosen-dosen senior yang sarat pengalaman.

b. Kualitas dan kompetensi dosen. Pada dasarnya, kualitas dan kompetensi dosen sesuai dengan standar kompetensi yang ditetapkan kementerian agama RI. Hanya saja, jumlah rasio dosen dengan jumlah rombel yang tidak berimbang, telah memaksakan distribusi mata kuliah tidak lagi berdasarkan kompetensi keilmuan. Banyak dosen yang mengampu mata kuliah diluar dasar keilmuannya.

c. Kepemimpinan menjadi faktor yang diabaikan oleh mahasiswa. Mereka tidak menempatkan faktor kepemimpinan sebagai hal mempengaruhi keputusan mereka.

\section{Pengaruh process terhadap keputusan mahasiswa memilih kuliah di IAIN Parepare.}

Menurut Hamdani dan Lupiyoadi, process merupakan gabungan semua aktivitas, umumnya terdiri atas prosedur, jadwal pekerjaan, mekanisme, aktivitas dan hal-hal rutin, dimana jasa diihasilkan disampaikan kepada konsumen. Secara garis besar, process yang terjadi dalam perguruan tinggi meliputi, yaitu proses pendaftaran, proses administrasi, dan proses akademik yang meliputi proses perkuliahan, proses ujian, proses praktek lapangan, dan lain-lain.

Hasil penelitian ini menunjukkan bahwa variabel process berpengaruh secara positif dan signifikan terhadap keputusan mahasiswa memilih kuliah di IAIN Parepare. Hal tersebut mengindikasikan bahwa indikator-indikator variabel process berhubungan secara linier dengan keputusan mahasiswa. Jika variabel process berjalan dengan baik maka akan berkontribusi terhadap keputusan mahasiswa memilih kuliah di IAIN Parepare. 


\section{Pengaruh physical evidence terhadap keputusan mahasiswa memilih kuliah di IAIN} Parepare.

Menurut Phillip Kotler, physical Evidence atau bukti fisik adalah bukti yang dimiliki penyedia jasa yang ditujukan kepada konsumen sebagai usulan nilai tambah konsumen. physical Evidence merupakan lingkungan tempat jasa disampaikan dan tempat penyedia jasa dengan konsumen berinteraksi beserta dengan semua komponen lainnya yang mendukung terwujudnya atau terkomunikasinya jasa. Dalam perguruan tinggi, physical Evidence merupakan lingkungan dimana mahasiswa dan institusi perguruan tinggi dapat berinteraksi.

Hasil penelitian ini menunjukkan bahwa variabel physical evidence berpengaruh secara positif dan signifikan terhadap keputusan mahasiswa memilih kuliah di IAIN Parepare. Hal tersebut mengindikasikan bahwa indikator-indikator variabel physical evidence berhubungan secara linier dengan keputusan mahasiswa. Jika variabel physical evidence dapat diadakan maka akan berkontribusi terhadap keputusan mahasiswa memilih kuliah di IAIN Parepare.

Ada pun indikator-indikator dari physical evidence dapat dijelaskan sebagai berikut :

a. Dalam konteks IAIN Parepare, sarana dan prasarana kampus cukup memadai. Telah tersedia gedung kantor, gedung perkualiahan, gedung perpustakaan yang mewah, gedung laboratorium, pusat kegiatan mahasiswa, mesjid, auditorium, pusat olaraga, dan lain-lain.

b. Konstruksi gedungnya pun cukup mewah, khususnya gedung-gedung yang baru dibangun. Topografi kampus yang berbukit-bukit dengan hamparan laut di depannya menjadi panorama yang menambah daya estetika kampus.

c. Tata ruang kampus yang ditunjang dengan kebersihan memberikan kenyamanan tersendiri bagi seluruh civitas akademika IAIN Parepare.

d. Asrama dan alat transportasi kampus juga telah terpenuhi. IAIN Parepare telah menyediakan tiga asrama mahasiswa, yaitu asrama putra, asrama putri dan asrama tahfiz al-Quran.

\section{KESIMPULAN}

A. Variabel product memiliki pengaruh yang positif dan signifikan terhadap keputusan mahasiswa memilih kuliah di IAIN Parepare. Artinya bahwa indikator-indikator dari variabel produk, yaitu a) Kualitas/mutu pendidikan; b) Prospek bagi lulusannya 
memperoleh pekerjaan dan karir; c) Banyak jurusan/program studi; d) Status akreditasi/negeri menjadi petimbangan utama mahasiswa memilih kuliah di IAIN Parepare. Semakin baik poduct yang diberikan, keputusan mahasiswa kuliah di IAIN Parepare juga akan meningkat;

B. Variabel price memiliki pengaruh yang negatif atau tidak pengaruh terhadap keputusan mahasiswa memilih kuliah di IAIN Parepare. Hal ini mengindikasikan ada hubungan yang tidak linier antara variabel harga dengan keputusan ma hasiswa. Artinya, jika harga pendidikan yang dikeluarkan mahasiswa meningkat, maka keputusan mahasiswa memilih kuliah di IAIN Parepare akan menurun. Sebaliknya, jika harga pendidikan rendah maka keputusan mahasiswa memilih kuliah di perguruan tinggi tersebut akan meningkat.

C. Variabel place berpengaruh secara positif dan signifikan terhadap keputusan mahasiswa memilih kuliah di IAIN Parepare. Hal tersebut mengindikasikan bahwa indikator-indikator variabel place berhubungan secara linier dengan keputusan mahasiswa. Jika variabel place tersedia maka keputusan mahasiswa memilih kuliah di IAIN Parepare akan meningkat;

D. Variabel promotion berpengaruh secara positif dan signifikan terhadap keputusan mahasiswa memilih kuliah di IAIN Parepare. Hal tersebut mengindikasikan bahwa indikator-indikator promotion berhubungan secara linier dengan keputusan mahasiswa. Jika variabel promotion dilakukan dengan baik dan terprogram maka keputusan mahasiswa memilih kuliah di IAIN Parepare akan meningkat;

E. Variabel people berpengaruh secara negatif atau tidak berpengaruh terhadap keputusan mahasiswa kuliah di IAIN Parepare. Hal ini mengindikasikan ada hubungan yang tidak linier antara variabel people dengan keputusan mahasiswa. Artinya, indikator-indikator dari variabel people tidak berkontribusi terhadap keputusan mahasiswa memilih kuliah di IAIN Parepare.

F. Variabel process berpengaruh secara positif dan signifikan terhadap keputusan mahasiswa memilih kuliah di IAIN Parepare. Hal tersebut mengindikasikan bahwa indikator-indikator variabel process berhubungan secara linier dengan keputusan mahasiswa. Jika variabel process berjalan dengan baik maka keputusan mahasiswa memilih kuliah di IAIN Parepare akan meningkat;

G. Variabel physical evidence berpengaruh secara positif dan signifikan terhadap keputusan mahasiswa memilih kuliah di IAIN Parepare. Hal tersebut mengindikasikan bahwa indikator-indikator variabel physical evidence berhubungan secara linier dengan keputusan 
mahasiswa. Jika variabel physical evidence dapat diadakan dengan meningkatkan kualitas dan kuantitasnya maka keputusan mahasiswa memilih kuliah di IAIN Parepare akan meningkat.

\section{DAFTAR PUSTAKA}

Alma, Buchari. 2007. Manajemen Pemasaran dan Pemasaran Jasa. Edisi Revisi, Bandung: Alfabeta

Algyansyah, Devilia. 2014. Pengaruh Bauran Pemasaran Jasa Terhadap Keputusan Pembelian Konsumen (Studi Kasus Konsumen Siete Cafe \& Garden Bandung).

Choirul, Nafisa, Tri, 2013. Pengaruh Kualitas Layanan dan Harga Terhadap Kepuasan Pelanggan Jasa Transportasi Ojek Online (Studi pada Konsumen Go-Jek Di Surabaya).

Collins, Harper. 2005. Kamus Ekonomi Lengkap. Edisi II, Jakarta: Erlangga.

Daryanto. 2011. Sari Kuliah Manajemen Pemasaran. Bandung: PT. Sarana Tutorial Nurani Sejahtera, CV. Yrama Widya

Daryanto S.S. 1997. Kamus Bahasa Indonesia Lengkap. Surabaya: Apollo.

Engel, James F, ed al. 1994. Perilaku Konsumen. Edisi Keenam. Jilid 1. Jakarta: Penerbit Binarupa Aksara.

Hurriyati, Ratih. 2008. Bauran Pemasaran dan Loyalitas Konsumen. Bandung: Alfabeta.

Kotler, Philip. 1994. Manajemen Pemasaran (Analisis, Perencanaan, Implementasi dan Pengendalian). Jakarta: Erlangga.

Kotler, Philip, 1997, Manajemen Pemasaran Marketing Manajemen 9e Edisi 2 (Analisis, Perencanaan, Implementasi, dan Kontrol), Jakarta, PT. Prenhalindo.

Kotler, Philip dan Amstrong, Garry. 2007. Dasar-dasar Pemasaran. Edisi Kesembilan. Jilid 1. Jakarta: PT. Indeks.

Kotler, Philip dan Kevin, Lane Keller. 2008. Manajemen Pemasaran. Edisi Keduabelas. Cetakan Ketiga. Jakarta: PT. Indeks.

Kotler, Philip and Amstrong, Garry. 2008. Prinsip-prinsip Pemasaran. Edisi Keduabelas. Alih Bahasa Bob Sabran, M. M. Jakarta : Erlangga.

Lamb, Charles W. ed al. 2001. Pemasaran (Marketing). Jakarta: Salemba Empat.

Lapiyoadi, Rambat. 2006. Manajemen Pemasaran Jasa; Teori dan Praktek. Edisi I, Jakarta: Salemba Empat.

Paney, Adrian. 2001. The Esence of Sevice Marketing. Diterjemahkan oleh Fandy Cipto. Yogyakarta: Pernerbit Andi.

Radiosunu. 1993. Manajemen Pemasaran, Suatu Pendekatan Analisis. Edisi Kedua. Cet. III. Yogyakarta: BPFE

Setiadi, Nugroho J. 2003. Perilaku Konsumen. Jakarta: PT. Kencana Prenanda Media. 
Volume. 13, Nomor 2, Desember 2017

Halaman. 18-38
Anatisis Pengaruh Bauran Pemasaran

Terhadap Keputusan Mahasiswa Memilih Kuliah di IAIN Parepare

Sugiyono.2006. Statistik Untuk Penelitian. Bandung: Alfabeta.

Tjiptono, Fandy. 2008. Manajemen Jasa, Yogyakarta: Andi Offset.

Yazid. 2001. Pemasaran Jasa : Konsep dan Implementasi. Edisi kedua. Yogyakarta: Econsia, Fakultas Ekonomi UII 